\title{
Bortezomib Induced Congestive Cardiac Failure in a Patient with Multiple Myeloma
}

\author{
Multipl Myelomalı Bir Hastada Bortezomib ilișkili Konjestif Kalp Yetmezliği
}

\author{
Gülden Sincan', Yusuf Bilen', Fuat Erdem', Suat Sincan², Emrah Aksakal ${ }^{3}$ \\ ${ }^{1}$ Atatürk University, Faculty of Medicine, Department of Haematology; ${ }^{2}$ Family Health Center; ${ }^{3}$ Department of Cardiology, \\ Erzurum, Turkey
}

\begin{abstract}
Bortezomib is a proteasome inhibitor commonly used for the treatment of multiple myeloma, and it has some cardiac side effects. The incidence of cardiac failure associated with bortezomib therapy in clinical trials remains incidental. We describe a 82-year-old patient with International Staging System Stage III multiple myeloma. Combined chemotherapy with bortezomib $1.3 \mathrm{mg} / \mathrm{m}^{2}$ on days 1, 8, 15, 22 of each cycle and $40 \mathrm{mg} /$ day dexamethasone (days 1 to 4) was started to him. Two days after the end of the 3rd cycle of chemotherapy (12th dose of bortezomib), he admitted with mild edema of bilateral lower extremity. Echocardiography revealed a drop in the left ventricular ejection fraction from pretreatment levels of $>55 \%$ to $30-35 \%$. Therefore; bortezomib treatment was postponed and he was treated for congestive heart failure. The patient's symptoms improved and the ejection fraction normalized after three months following discontinuation of bortezomib.
\end{abstract}

Key words: bortezomib; congestive heart failure; multiple myeloma

\section{ÖZET}

Bortezomib genellikle multipl myeloma tedavisi için kullanılan bir proteazom inhibitörüdür ve bazı kardiyak yan etkilere sahiptir. Klinik çalıșmalardaki bortezomib tedavisiyle ilișkili kalp yetmezliği insidansı tesadüfi olarak kalır. Biz Uluslararası skorlama sistemine göre Evre 3 multipl myeloması olan 82 yașında bir hastayı sunuyoruz. Bu hastaya kombine kemoterapi (her bir siklusta bortezomib 1,3 $\mathrm{mg} / \mathrm{m}^{2}$ D1, D8, D15, D22 ve $40 \mathrm{mg} / g u ̈ n$ deksametazon [D1-4]) bașlandı. Kemoterapisinin 3 siklusunun tamamlanmasından 2 gün sonra (bortezomib tedavisinin 12. dozu) hasta bilateral alt extremitelerde hafif ödem nedeniyle bașvurdu. Ekokardiyografide ejeksiyon fraksiyonun tedavi öncesi >\%55'den \%30-35'e düștügünü gösterdi. Bu nedenle bortezomib tedavisi kesildi ve konjestif kalp yetmezliği için hasta tedavi edildi. Bortezomib kesilmesinden 3 ay sonra hastanın klinik semptomları düzeldi ve ejeksiyon fraksiyonu normale döndü.

Anahtar kelimeler: bortezomib; konjestif kalp yetmezliği; multipl myeloma

Uzm. Dr. Gülden Sincan, Erzurum, Türkiye, Tel. 05052724264

Email.guldensincan@gmail.com

Geliş Taribi: 20.09.2015 • Kabul Taribi: 06.03.2017

\section{Introduction}

Bortezomib is an antineoplastic drug which was originally synthesized in 1995 . Firstly, the drug was tested in a small phase I clinical trial on patients with multiple myeloma, and the treatment with bortezomib was approved for initial treatments of patients with Multiple Myeloma by the Food and Drug Administration (FDA) in 2008. Also, the bortezomib was approved for the treatments of non-Hodgkin lymphoma, Waldenström's macroglobulinemia, and systemic light chain amyloidosis, among others by FDA.

It was documented that bortezomib has several side effects that necessitates abruption or sometimes cessation of the therapy. It is associated with peripheral neuropathy in $30 \%$ of patients; occasionally, it can be painful. In addition, myelosupression causing neutropenia and thrombocytopenia can also exist and be dose-limiting. Another side effect of Bortezomib is shingles, but this problem can be prevented with prophylaxis of acyclovir ${ }^{1}$. Gastro-intestinal effects and asthenia are the most common adverse events ${ }^{2}$. The incidence of cardiac failure or other cardiovascular effects associated with bortezomib remains incidental. Herein, we present the case of an 82-year-old male patient who devoloped temporary heart failure secondary to bortezomib based chemotherapy because of rarity.

\section{Case}

A 82 year-old male patient admitted to our clinic with pain on his back and weakness. He had no prior cardiac history and no additional risk factor except from his age for cardiac disease. On evaluation of his routine laboratory tests, he was found to have haemoglobin of $8.7 \mathrm{~g} / \mathrm{dl}$, haematocrit of $26.6 \%$, white blood 
cell (WBC) count of $10.200 / \mathrm{mm}^{3}$ and platelet count of $148000 \mu / \mathrm{l}$. Level of serum urea was $67 \mathrm{mg} / \mathrm{dl}$, creatinine $3 \mathrm{mg} / \mathrm{dl}$, sodium $129 \mathrm{mEq} / \mathrm{L}$, potassium 4.46 $\mathrm{mEq} / \mathrm{L}$, uric acid $11.7 \mathrm{mg} / \mathrm{dl}$, total protein $9.5 \mathrm{mg} /$ $\mathrm{dl}$, albumin $2.8 \mathrm{mg} / \mathrm{dl}$, aspartate aminotransferase 27 $\mathrm{UI} / \mathrm{L}$, alanine aminotransferase $13 \mathrm{UI} / \mathrm{L}$, gamma glutamyl transferase $14 \mathrm{U} / \mathrm{L}$, IgG $44.05 \mathrm{~g} / \mathrm{L}, \operatorname{IgA} 0.26$ $\mathrm{g} / \mathrm{L}, \operatorname{IgM} 0.19 \mathrm{~g} / \mathrm{L}$. Tests of thyroid function was normal. Diffuse osteopenia confirmed with the graphies of bone survey. Due to the presence of severe anemia and osteopenia, diagnosis of multiple myeloma was considered. Monoclonal protein band was examined by the use of serum protein electrophoresis and the immunofixation electrophoresis showed monoclonal immunogobulin bands of IgG-Kappa. The level of beta- 2 microglobulin was 7.49 . Bone marrow aspiration and biopsy confirmed to the diagnosis of International Staging System stage III multiple myeloma. Electrocardiography was normal and transthoracic echocardiography revealed a left ventricular EF value of this patient $>55 \%$ by modified Simpson method.

The patient treated with three cycles of bortezomib $1.3 \mathrm{mg} / \mathrm{m}^{2}$ on days $1,8,15,22$ of each cycle and $40 \mathrm{mg} /$ day dexamethasone (days 1 to 4 ). With the bortezomib based chemotherapy the level of creatinine decreased to its normal ranges in our patient. However, two days after the end of third cycle of therapy the patient reported that he has an increase on fatigue, mild dyspnea and mild edema of lower extremity. He did not experience any chest pain or myalgia. Pulmonary auscultation revealed crepitation of bilateral basillar region of the lungs in physical examination. Bilateral mild edema was present from the dorsalis pedis to the ankles. ECG did not show any signs of ischemia. The chest X-Ray graphy showed an increased heart-chest ratio. Thus, the patient consulted with cardiologists. The serum levels of cardiac enzymes (creatinine kinase-MB, troponin) were in normal ranges. Echocardiography was applied to the patient by same cardiologist and global hypokinesia was confirmed. Ejection fraction was estimated to be 30-35\% by modified Simpson method. Coronery anjiography was not performed because the patient did not gived informed consent. Therefore, Bortezomib based chemotherapy was terminated. The anti-myeloma treatment of this patient was reconstituted to melphalan and prednisolone. The patient was treated for congestive heart failure with diuretics, angiotensin-converting enzyme inhibitors and beta blockers.
The patient responded well to this treatment. The ejection fraction and global hypokinesia normalized after three months.

\section{Discussion}

Bortezomib, a dipeptidyl boronic acid, is selective and reversible inhibitor of the chymotrypsin-like activity of the $26 \mathrm{~S}$ proteasome. The ubiquitin-proteasome pathway plays an essential role in regulating the intracellular concentration of ubiquitylated proteins. Inhibition of the ubiquitin-proteasome system has been shown to lead to hyperubiquitination of intracellular proteins ${ }^{3}$. It may prevent degradation of pro-apoptotic factors and inhibition results in the increase of apoptosis ${ }^{4}$. Bortezomib, by inhibiting ubiquitin-proteasome pathway, would lead to accumulation of ubiquitinated proteins in cardiac myocytes $^{5}$. None of necrotic or apoptotic cells are found in histopathological heart examination and no rise in troponin I levels ${ }^{6}$.

Orciuolo et al. reported 8 cases (11.6\%) with cardiotoxicity ranging from heart failure to arrhythmias in 69 cases $^{7}$. The APEX trial reported seven patients who developed congestive heart failure. In this study, the incidence of congestive cardiac failure was $2 \%$ in both bortezomib and high dose dexamethasone group. In the SUMMIT and CREST trials, the incidence of cardiac failure associated with bortezomib therapy was very low. Most of the cases used other chemotherapeutic agents including cardiotoxic anthracyclines in the trials. In a phase III study using bortezomib as a first line agent combined with melphalan and prednisone, no incidence of cardiomyopathy was documented ${ }^{8}$. The incidence of cardiotoxicity that associated with treatment of bortezomib ranges from $0 \%$ to $5 \%$ in various studies?.

Up to now; very few cases with heart failure that associated with bortezomib treatment have been reported in the literature ${ }^{10}$. In our patient; baseline left ventricular function was normal. Heart failure devoloped after bortezomib-based treatment (total 15.6 $\mathrm{mg} / \mathrm{m}^{2}$ ). Cumulative dose of the drug administered to patient ranged from $0.7 \mathrm{mg} / \mathrm{m}^{2}$ to $31.2 \mathrm{mg} / \mathrm{m}^{2}$ in the literature. All cases showed improvement in left ventricular ejection fraction following discontinuation of bortezomib in the literature. The ejection fraction returned to normal after three months following discontinuation of bortezomib in our case similarly with the literature. 
Congestive heart failure is rarely occured important toxicity associated with treatment of bortezomib. Patients with history of cardiac diseases or use of anthracycline drugs may be at increased risk for bortezomib related congestive heart failure. Therefore, we recommend close monitoring of the cardiac parameters in patients undergoing this therapy.

\section{References}

1. Oakervee HE, Popat R, Curry $\mathrm{N}$ et al. PAD combination therapy (PS-341/bortezomib, doxorubicin and dexamethasone) for previously untreated patients with multiple myeloma. Br J Haematol 2005;129(6):755-62.

2. Pour L, Adam Z, Buresova L, Pour L, et al. Varicella-zoster virus prophylaxis with low-dose acyclovir in patients with multiple myeloma treated with bortezomib. Clinical Lymphoma \& Myeloma 2009;9(2):151-53.

3. Okada K, Wangpoengtrakul C, Osawa T, et al. 4-Hydroxy2-nonenal-mediated impairment of intracellular proteolysis during oxidative stress. Identification of proteasomes as target molecules. J Biol Chem 1999;274(34):23787-93.
4. Dou QP, Li B. Proteasome inhibitors as potential novel anticancer agents. Drug Resist Updat 1999;2:215-33.

5. Birks EJ, Latif N, Enesa K, et al. Elevated p53 expression is associated with dysregulation of the ubiquitin-proteasome system in dilated cardiomyopathy. Cardiovasc Res 2008;79(3):472-80.

6. Nowis D, Maczewski M, Mackiewicz U et al. Cardiotoxicity of the anticancer therapeutic agent bortezomib. Am J Pathol 2010;176:2658-68.

7. Enrico O, Gabriele B, Nadia C, et al. Unexpected cardiotoxicity in haematological bortezomib treated patients. $\mathrm{Br} \mathrm{J}$ Haematol 2007;138:396-97.

8. San Miguel JF, Schlag R, Khuageva NK, et al. Bortezomib plus melphalan and prednisone for initial treatment of multiple myeloma. N Engl J Med 2008;359(9):906-17.

9. Mateos MV, Richardson PG, Schlag R, et al. Bortezomib plus melphalan and prednisone compared with melphalan and prednisone in previously untreated multiple myeloma: updated follow-up and impact of subsequent therapy in the phase III VISTA trial. J Clin Oncol 2010;28:2259-66.

10. Aota Y, Gotoh A, Hanyu N, et al. Bortezomib-associated acute congestive heart failure in a patient with multiple myeloma. Rinsho Ketsueki 2015;56(1):44-7 